\title{
BEYOND THE STRAIT: PLA MISSIONS OTHER THAN TAIWAN
}

\author{
Roy Kamphausen \\ David Lai \\ Andrew Scobell
}

Editors

\begin{abstract}
April 2008
The views expressed in this report are those of the authors and do not necessarily reflect the official policy or position of the Department of the Army, the Department of Defense, or the U.S. Government. This report is cleared for public release; distribution is unlimited.

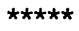

This publication is subject to Title 17, United States Code, Sections 101 and 105. It is in the public domain and may not be copyrighted.
\end{abstract}

